\title{
The African Conception of Sacrifice and its Relationship with Child Sacrifice
}

\author{
Paul Bukuluki $^{1, \star}$, Christine Mbabazi Mpyangu ${ }^{2}$ \\ ${ }^{1}$ Department of Social Work and Social Administration, School of Social Sciences, \\ College of Humanities and Social Sciences, Makerere University, Kampala, Uganda \\ ${ }^{2}$ Department of Religion and Peace Studies, College of Humanities and Social Sciences, \\ Makerere University, Kampala, Uganda \\ `E-mail address: pbukuluki@gmail.com , pbukuluki@ss.chuss.mak.ac.ug
}

\begin{abstract}
Although the practice of human sacrifice is not new in the mythology around sacrifice in Africa, the practice of child mutilation and sacrifice at least in Uganda was just spoken about as fairytale. However events that have unraveled since the late 1990s have shocked the country with real cases of children being mutilated and killed in the context of what is commonly referred to as child sacrifice in Uganda. This paper presents the "African" meaning of the concept sacrifice and how demonstrates how the in African religious theology disassociates itself from murder and mutilation of children's body parts as part of the rituals for healing, dealing misfortunes or even prevention of unfortunate events. There was consensus from our study participants that although historically, there has been human and child sacrifice in the African and Uganda cultural mythology, the actual practice of these vices is a new phenomenon, not recognized and accepted in indigenous/traditional religious theology and practice of African religion and culture.
\end{abstract}

Keywords: Sacrifice; religion; culture; children; child protection

\section{INTRODUCTION}

The working definition of child sacrifice leans more to that of the National Task Force against Child Sacrifice in Uganda. Child Sacrifice and the mutilation of children is conceptualized as the "harmful practice of removing a child's body parts, blood or tissue while the child is alive which often results in death. These body parts, blood or tissue are worn, buried or consumed in the belief they will benefit an individual or community" . Although the practice of human sacrifice is not new in the mythology around sacrifice in Africa, the practice of child sacrifice is at least in Uganda was just spoken about as fairytale. We used to hear stories and legends while growing up that people kidnap children and spill their blood when they build industries, particularly maize mills (these were the most common industries while we were growing up in the early 1970s), build dams, construct large establishments.

\footnotetext{
${ }^{1}$ Minutes of the Technical Working Group against Child Sacrifice (May 2013).
} 
However in the mid 1990s until now, we have seen what used to be a fairytale turn into something real that happens in our society. Some of the authors (Atekyereza et al, 2014) have attributed the sudden increase in its occurrence of child sacrifice and mutilation in recent years to socio-cultural and socio-economic factors. The term sacrifice as used in this African religious theology has been contested as not appropriate to be used in the context of murder and mutilation of children's body parts in the belief they will benefit an individual, family or community. There was consensus however, that historically, there has been human and child sacrifice in the African and Uganda cultural mythology, but child and/or human sacrifice as an actual practice is a new phenomena, not recognized and accepted in indigenous/traditional religious theology and practice. Child/human sacrifice was perceived to be alien to the prevailing beliefs and practices associated with sacrifice as they are conceptualized and articulated through the indigenous religious and healing cultures in Uganda by healers and the community.

John S. Mbiti, in his book Introduction to African Religion (1977: 63-66) argues that, "in African societies sacrifice was very common and that most, involved shedding of blood of a human being or an animal." He adds that in African societies, life is closely associated with blood. So, when blood is shed in a sacrificial context, it implies that human or animal life is being given back to God who is, in fact, the ultimate source of all life. According to Mbiti (1975: 55-56), common routines like "good health, healing, protection from danger, safety in traveling or some other undertaking, security, prosperity, preservation of life, peace and various benefits for individuals" have religious connotations. Mbiti adds that "for the community at large, prayer may ask for rain, peace, the cessation of epidemics and dangers to the nation, success in war or raids, the acceptance of sacrifices and offerings, and fertility for people, animals and crops" (Mbiti 1975: 55-56).

There is concern with the terminology used to describe "child sacrifice". To many stakeholders, the concept sacrifice carries a positive value and meaning. Sacrifice is a common phenomenon in the African indigenous religions, cultural practices as well as in the dominant - conventional religions. It constitutes an important part of worship, prayers and thanksgiving. The Luganda term sadaaka which is translated to mean sacrifice means to give up something very valuable and close to an individual. Interviews with traditional healers quite clearly indicated that sadaaka entails giving up something highly treasured. It also denotes giving up something to which a high value is attached. Sacrifice in traditional healing involves killing an animal in a ceremony and the person undertaking the sacrifice should have a deep and personal attachment to the sacrificial object.

Sacrifice- there must be an attachment to what you sacrifice. It must have value to you but not to another person. You cannot sacrifice what does not belong to you. You cannot go to the market to buy a cow or chicken and then present it as a sacrifice to the spirits. That is an acquired item. A sacrificial object must be something you already possess and value deeply (Traditional healer, PROMETRA)

Focus group discussions with community members during a rapid assessment carried out by Ministry of Gender Labour and Social Development also revealed similar perceptions of sacrifice. Male community members noted that sacrifice in traditional practice involved offering animals to the gods as an act of thanksgiving, or in an effort to secure protection and long life. 
“... Those days, people would sacrifice to make life longer. Sacrifice was also common when young babies were born. Chicken and other animals would be slaughtered and some of the body organs like the hearts and kidneys which would be buried together with the removed part of the umbilical cord of the new born babies. But these days people say that chicken and animals do not work and that's the reason they have turned to child sacrifice" (Men's FGD, Oyam District, Northern Uganda)

This illustrates that the current practice of child sacrifice, which sometimes involves abducting, killing and mutilation of children who are in most cases, non biological, and not connected to the 'sacrificer' either by blood or affinity might be a form of manipulation by those involved (MoGLSD, 2010).

Focus Group Discussions with traditional healers in Masaka district Central Uganda during the rapid assessment on child sacrifice for the MOLSD (2010) revealed that in traditional healing, the sacrificial object depends on the reason for the sacrifice. The object is however determined or dictated by the power or authority to whom the sacrifice is being made. In this regard, the sacrificial object must be clearly defined, by the spirits that demand the sacrifice. Sacrificial objects range from plants to animals, and each type of object has some significance attached to it. The sacrificial object also signifies the magnitude of the problem or issue for which the sacrifice is being made.

"Offering sacrifices is a cultural practice. The issue is: "how is the ritual carried out, what is sacrificed and what does it mean?" Ritual related sacrifice has been a part of our practice, right from the time of our grandparents. They would first of all establish why they have to carry out the sacrifice. They would start with chicken [enkoko] so as to get rid [okukokola meaning to take away calamities $\left.{ }^{2}\right]$ of all problems. They would then sacrifice goats [embuzi ${ }^{3}$ ] to eliminate [okubuza meaning to conceal] all problems. They would sacrifice sheep to stop all problems [okuliga $a^{4}$ meaning to defeat] that have afflicted an individual or the community. And finally they would sacrifice a cow [ente ${ }^{5]}$ to discharge all problems affecting life of individuals and the community. (FGD with traditional healers, Masaka, Central Uganda)

A focus Group discussion with representatives of Associations for Traditional Healers in Uganda also indicated similar findings but linked different sacrificial objects to specific spirits especially in the Baganda culture which dominates the central region of Uganda. It was noted that a white goat is sacrificed to the god 'Mukasa', while black goats are reserved for spirits of the dead. A 'hairy goat' is sacrificed for another spirit called 'ekitambo', while doves and white chicken are sacrificed for ginis ${ }^{6}$. To the god Kiwanuka, a 'red' sheep is offered as a sacrifice. In addition, all living things that are sacrificed are also eaten by those involved in the ritual, especially by the ritual facilitators.

All interviews with healers in this study demonstrated that human and child sacrifice was not part of the traditional social construction of sacrifice and healing of illnesses or

\footnotetext{
${ }^{2}$ Enkoko, a Kiganda word for chicken rhymes with okukokola, which means getting rid of calamities

${ }^{3}$ Embuzi is a Luganda word for goat and sounds like okubuza, which means to make something disappear, or to lose something

${ }^{4}$ Okuliga is a luganda word for defeat, and rhymes with endiga, which is the word for sheep

${ }^{5}$ Ente is the luganda word for cow but also sounds like entee which means, letting go

${ }^{6}$ This is believed to be a spirit that sometimes manifests itself in human form
} 
misfortunes. They described as an alien phenomenon. They distanced themselves from healers involved in child sacrifice and mutilation of children by calling them "killers".

\begin{abstract}
"In our indigenous practice, there is no situation requiring human or child sacrifice, and there is no one to eat the carcass, as is the case in sacrifices. Every sacrificial object must be edible and eaten. Those who sacrifice people are killers and not healers" (FGD, NACOTHA) (Also see MoGLSD, 2010)

"On our side as traditional healers our culture does not allow us to sacrifice human beings. Even when carrying out rituals you are not supposed to touch human blood. If you accidentally cut your finger while slaughtering an animal for sacrifice or preparing protective medicine we take it that the sacrifice or medicine won't work. So we do not involve human flesh or dead bodies in our operations. Some of us do not even attend burials. Those who do before you touch any medicine you must wash your hands properly. For that matter I would like to say human sacrifice is something new" (FGD, Traditional Healers Masaka, Central Uganda) (Also see MoGLSD, 2010)
\end{abstract}

This illustrates that human blood is not a part of the traditional healing practice. Traditional healers denied that child sacrifice is a part of their practice. There was consensus in all community discussions and interviews, that child and human sacrifice is a new practice, which is not recognized in indigenous traditional religious rituals and worship. Nonetheless, respondents acknowledged that the concept has always existed as a myth, but there was never any real evidence of actual occurrence of child sacrifice. Respondents reported hearing about the problem, in their communities when they were growing up, but could not recall any actual occurrence of this practice. Rumors of child sacrifice were in the past linked to 'big' projects, such as construction. It was generally said that projects of this nature required a sacrifice of human blood to be accomplished (also see MoGLSD, 2010).

This meaning of sacrifice is similar to that of Mbiti (1975) who argued, "Sacrifices are defined as blood offerings. There is mention of sacrificing in time of need an animal of one colour, belonging to an upright person. What has been sacrificed may be consumed by priests, by participants in the ritual, left at the ritual site, or returned to the owner. There are intermediaries, gods and spirits, between God and humans" (Mbiti, 1975: 55-56).

It emerged quite clearly that there is belief in the efficacy of sacrifices (not necessary those involving human/child sacrifice) and today in various communities there is a belief that when one gives the best of what he has then success prosperity and fecundity will follow as a result.

A vivid example of such a belief can be derived from among the Acholi of Northern Uganda. In the recent past when they were returning to their villages from the Internally Displaced People's Camps (IDPCS). A ritual Moyo Cer (cleansing a vast land) is performed to cleanse the land. In the course of that performance a sheep is sacrificed to cleanse the land, so that all will go well, peace will prevail, women and the land will be fertile. This is believed to be very important and it works for them as much as they believe it and it reveals a traditional belief system present in that land.

In this chapter, we indicate that sacrifice is a concept and phenomenon well appreciated and that different situations do call for it. For example, at the start of a new project, completion and success of an event, in times of calamities and catastrophes, among others. Yet, it emerges clearly that child sacrifice, though noticeably present in different communities in the world, was not that common in most African traditional societies. Partly, this could be attributed to the significance and value that was attributed to children. On the contrary, today, 
with the prevalence of child sacrifice, children are kidnapped and decapitated for various reasons. Some of the reasons include organ trafficking, serenity of economic prosperity and success as well as consecration of buildings etc.

The French Anthropologist Rene Girard notes that in "many rituals the sacrificial act assumes two opposing aspects, appearing at times as a sacred obligation to be neglected at grave peril, at other times as a sort of criminal activity entailing perils of equal gravity." (Girard in Grimes, 1996: 240). What Girard notes here is worth a reflection, because any sacrificial act, indeed, seems to have a sacred dimension which should not be ignored, yet on the other hand it appear to be a criminal act. With regard to child sacrifice, it is ordinarily impossible to think of it as a sacrifice but rather as a grave crime.

It is our opinion a crime because precious innocent lives are lost, not only lost but brutally. In most cases, the children are suffocated to death, heads cut off, and sometimes buried alive. At this point it is vital to ask a question, namely; what has happened to the sanctity of life? Why has life been reduced to nothing or is it economy?

In many African communities and even in the declaration of the fundamental human rights, life was seen as sacred and it had to be preserved. Yet, in the act of sacrificing children and mutilating children in most cases leading to death, this begets controversy.

Do prevailing beliefs in superstition and sacrifice to appease spirits and gods make African communities susceptible to engaging in abuse of child through child sacrifice? It was noted that the prevailing strong beliefs in spirits, gods, superstition and relationship with the living dead and their supernatural has created an enabling environment for ritual murders involving children to thrive. As noted by Mbiti (1975), Africans are notoriously religious. Everything an "African" does including planting, harvesting, sex, producing children and naming them, fertility and bareness, wealth and wellbeing, leadership, moving from one stage of life to another (liminality and initiation from childhood to adulthood) etc have a religious dimension. Janzen (1998: 164) cited Jean Pouillon's comparative framework of healing structure while working among the Dangeleat of Chad; where illness is held to be the doing of the Margai spirit genies attach the sufferer with not only affliction, but an appropriate identity as well; and the same spirit is said to signal the healer by attacking him as well, thus creating a doctor-patient relationship for the occasion, between whom an enduring patronage for the life of the two persons (the healer and the sufferer) is established. Such a relationship as already pointed out by Pouillon (1970), it is common that the patron (healer) may manipulate the situation to the extent that the sufferer does anything his patron asks of him since the healer may be presumed speaking for the spirits and to be holding an advanced standing to that of his client (patient). This kind of relationship can be equated to In this case therefore; anything can happen and can lay a firm base upon which child/human sacrifice may be sustained. For an 'African', there is an intimate relationship between the living and the living dead. When in a room alone, in a thick forest, in the dark, a cave or a mountain, a typical African will consciously or sub-consciously believe that though physically alone, he or she is connected with the spiritual world of the living dead (Mbiti, 1989).

Children are more likely to fall victims to sacrifice and mutilation compared to adults, because they are more easily lured and some people believe that that children are sacred and their body parts contain power believed to be either strengthen the effectiveness of traditional medicine or to address socio-economic misfortunes (Fellows, 2010; Fellows, 2013). In many of the cases that have been reported, "Children become victims of traffickers who kidnap or entice them from their parents or guardians using force, guile or bribery ${ }^{7}$. Police records

\footnotetext{
${ }^{7}$ Child sacrifice is on the rise in Uganda, The monitor, Aug 2006.
} 
indicate that interactions with survivors of child sacrifice and associated vices such as kidnapping reveal that they were exposed to these phenomena due to a number of factors including: "delay to go back home after school, going for visits, changing employments without informing others, loosing way back home from school, and elopement of some young girls with men" (Uganda Police Force, 2009: 2).

\section{SOME ANTHROPOLOGICAL PERSPECTIVES}

There is a close association between sacrifice and beliefs in superstition and traditional religious and healing practices. It is worth noting that the current spate of child sacrifice has widely been attributed to activities of traditional healers. A traditional healer is a person recognized by members of the community a provider of health care by using plant, animal and mineral substances and other methods which may be based on social, cultural and religious backgrounds, as well as knowledge and attitudes that are prevalent in the community regarding physical, mental and social wellbeing and the causes of disease and disability (WHO, 1978; PROMETRA, 2005). There are six main categories of traditional healers namely: herbalists, bonesetters, diviners, faith healers, spiritualists, and Traditional Birth Attendants (TBAs). Herbalists treat using herbs and also sell herbal preparations, while spiritualists use spiritual means to diagnose and health their patients. Faith healers are traditional health practitioner with strong religious faith. They evoke the power of the invisible to heal and solve problems. They are of any religious sect and use either the Bible or Quran in their healing activities.

Traditional medicine still enjoys an important place in Uganda and other developing countries. A number of authors have stated that $80 \%$ of the population in developing countries has its health care needs met through the traditional medicine sector (WHO 1978, 2002; Luoga et al. 2000, Ventevogel 1996 in Bukuluki, 2006). Traditional medicine is acceptable, accessible and affordable and negotiable by the majority of African people. Even though it was often denigrated as backward practice during the colonial era, it has continued to thrive because of its medicinal efficacy and cultural significance among the population.

Traditional medical explanatory models seem to fit squarely into the people's quest for illness explanations that are culture bound (Bukuluki, 2006). Evans-Pritchard (1976: 227) defined such medicine to mean any object in which mystical power is supposed to reside and which is used in magic rites; and that they are mainly of vegetable nature. George Foster (1998: 147) in "the Arts of Medical Anthropology Readings" argues that the kinds of curers found in a particular society, and the curing acts in which they engage, stem logically from the etiologies that are recognized. He notes that personalistic systems, with multiple levels of causation, logically requires curers with multiple supernatural and/or magical skills, for the primary concern of the patient and his family is not the immediate cause of illness, but rather 'Who'? And 'why'?

When they ask the question "Why me?" the traditional healers provide them with answers that are rooted in their socialization processes, cultural expectations and relationships with both the living and the "living dead" (Bukuluki, 2006). This is closely linked to the personalistic belief system, which perceives misfortune and illness to be as a result of seen, but more so unseen forces such as ancestors, spirits and enemies (also see Tabuti et al., 2003).

Within this line of argument, misfortune and illness is associated with one's relationship with people (especially relatives and friends) and the ancestral spirits (b'ajjajja abawumula), the nature spirits (misambwa), and gods (balubaale). Although misfortune and illness may 
have a physical immediate cause, the ultimate cause is in a number of cases linked to relationships with people and the spiritual world (Bukuluki, 2006). Consequently, people may decide to go to healers to find not only therapy but also the culturally bound answers to their questions arising from circumstances they cannot easily explain (Whyte, 1997). With the importance that society attaches to the work of traditional healers; whatever they say is not questioned. This in most case leave their patients with no other way out in instances where the healer asks for the most pure sacrifice to be offered for the appeasement of the spirits. Children may therefore fall victims to such dogma as human sacrifice may be demanded by the spirits. It provides acceptable answers to people who are attempting to question misfortunes that befell them and their families (Ibid).

As Evans-Pritchard put it, in his ethnography among the Azande, witchcraft explains unfortunate events. Control is re-established in an otherwise uncertain world. Evans-Pritchard is at pains to point out that the Azande are not ignorant of cause and effect (Ibid). They are simply 'foreshortening the chain of events and in a particular social situation are selecting the cause that is socially relevant and neglecting the rest' (Evans-Pritchard, 1976: 25). Thus if a man is killed by a spear in a skirmish with enemies the physiological cause of death is not socially relevant as there is nothing that can be done to bring the man back to life. What can be done is to identify the witch who guided that particular spear to that particular man and to punish him (or her). A witch is a person whose body contains, or is declared by oracles or diviners to contain, witchcraft substance and who is supposed to practice witchcraft (Ibid: 227) - "a supposed psychic emanation from witchcraft substance which is believed to cause injury to health or property" (Evan-Pritchard, 1976: 226). Hence if a man is killed by an elephant Azande say that the elephant is the first spear and that witchcraft is the second spear and that together they killed the man' (Ibid: 25-26)

Evans-Pritchard (1976: 33) in his ethnography among the Azande noted that if a misfortunate is incipient there is sound reason for immediate identification of the Witch responsible since he can be persuaded to withdraw his with-craft before the matter takes a serious turn. In such cases where the witch cannot find or the situation persists even after the suspected Witch is found, and the intended healer realizing that the situation is beyond his or her control and not wanting to admit defeat perhaps considering how much the patient has so far spent, may then make it difficult for the client by asking for difficult objects sometimes including human parts (say: private parts). However, this can turn out to be complex: the healer may use this strategy to get rid of the patient without any trouble to return what was paid for the services, yet a desperate patient in dire need of a solution goes on a hunt get what is required for the objects for sacrifice. This mere trickery from a healer presumed to be having supernatural power my in turn have a negative implication on the children who are most vulnerable thus an easy target which may end in child sacrifice.

The paradox is traditional healing and illness explanations, and beliefs in spirits have continued to thrive alongside Christianity and modernity. This practice cannot be explained using the notion of dualism which is value laden with clear demarcations between good and bad or good and evil, Christian and unchristian. It can rather be better explained by the concept of syncretism ${ }^{8}$, which shows that people can find ways of balancing two opposing forces in their fused self. In the public realm, they exhibit that they are they are Christians and in the private realm, they still have strong beliefs in the traditional/indigenous religious practices and beliefs. This is at variance with the Olaniyan's moral notions of the sacred (as

\footnotetext{
${ }^{8}$ Syncretism as defined by the American Heritage Dictionary is the reconciliation or fusion of differing systems of belief. This is most evident in the areas of philosophy and religion, and usually results in a new teaching or belief system.
} 
cited in Norval, 1999: 7) which has a strong inclination towards dualism and the absolute truth: conceptualized in terms of a "given totality, separated and separable from other cultures with exactness of a puritanical slide rule". In other words, elements of a culture are taken to be non-contradictory and non-antagonistic. This implies that the difference from other cultures is conceived as "absolute, closed and impenetrable" (Norval, 1999: 7-8).

This syncretism paradox can be better explained by the profane discourse, which "is synonymous with non purity and/or hybridity of identity of any culture." The profane discourse insists on the madness of culture and the eventedness of every identity. Culture is conceived as a complicated articulation of mutually contradictory and antagonistic elements". Norval adds that cultural identity from this perspective cannot be seen as closed and positive but it "exists as fragile and vulnerable - as a hybrid and non pure" (ibid).

The growing influence of the profane discourse, partly explains the sustained belief in spirits, superstition, and witchcraft alongside the dominant religions and modernity. EvansPrichard (1976: 56) in questioning whether Witches are conscious agents, noted that there seems that to some degree at any rate, people in a community in which the facts of witchcraft are never doubted may convince themselves that they possess the power with which others credit them. Similarly, this has fertile ground for practices that hinge on spirituality and personalistic belief systems that underlie the human sacrifice. This notwithstanding, there are other risk factors for child sacrifice such as organ trade which need further exploration.

\section{CULTURAL CONSTRUCTION OF A CHILD}

Children, many communities occupy an important in the family, community, nation and globally. It is heart-wrecking when one loses a child. But who is a child? What is in a child that is so significant that one should particularly reflect in order to see the problematic dimension of child sacrifice?

A child is begotten and by definition one that is between $0-18$ years of age. In many African communities a child can be as old as 50 years for as long as his parents are alive; they will call him a child. Besides, in some communities like the Bagisu of Eastern Uganda a male person is a child until he circumcise (which is a rite de passage) and this ushers him to adulthood which comes with responsibilities such as marriage. So, the definition of a child can be as dynamic as that, namely between age, social obligations and responsibilities as well as social expectations.

Reflecting upon the Biological dimension a child is as innocent as an egg. An egg has no opening, it is sealed and therefore purse. So, with regard to child sacrifice, the commonest age is $0-12$ years. This age bracket exhibits innocence. This aspect of innocence denotes purity and these two innocence and purity are vital aspects of a sacrifice. Man sacrifices that which is pure, and precious bearing in mind that sacrifice carries a connotation of sanctifying or consecrating an object (Henninger in Eliade 1987: 544). The comparison of a child and egg is made clearer to the Acholi interpretation of stepping on the egg ritual "nyono tongweno" which is performed to welcome anybody that has been away from the family for a prolonged period of time. The egg is believed to symbolize life. So in the case of sacrifice a child is like an egg which gives life. But how is one able to compare the cleansing or sanctifying effect of an egg and a child? It is this ethical problem of taking an innocent life in the name of performing a religious act. 
Children are called lutino in Acholi language and there are a very special category as this can be detected from how they are received at the time of birth. They are welcomed into the family and clan in a secret manner in which they stay inside the house for three or four days, if the child is a boy or girl respectively. When a child is born among the Acholi, it is important to observe how that child looks and take note of any special features which may be pointers to what kind of name that child will receive and whether the child is jok or not. For example a child born with extra fingers will be called Ajara if it is a girl and Ojara if it is a boy. The gender of the child is valuable among the Acholi because it will also determine what follows in terms of birth rituals. ${ }^{10}$ Elaborate rituals are performed to celebrate the coming of children born as twins.

We should at this juncture; point out that symbolism is a vital characteristic of all rituals. Davis-Floyd defines a symbol as "an object, idea, or action that is loaded with cultural meaning" (Davis- Floyd, 1992 cited in Grimes 1996: 149). This is important because a symbol may mean different things to different cultures. If an egg represents innocence and purity, what does a child represent then? A child cannot be reduced to an egg. Something deeper ought to be investigated with regard to child sacrifice. Perhaps that is why Luc de Heusch (1985: 215) noted that "One must listen patiently to the ideological speeches of a multitude of sacrifices, in the most diverse societies, before reaching a final conclusion."

Going back to symbolism, one important element that is obtained from children for sacrificial purposes is blood. This can be said to be a constituent of sacrifice that is indispensable. More over what makes it so powerful for good or evil is the fact that life is in it. Many people believe that blood that is offered will cleanse, scantly and preserve that which it was meant for. The blood obtained from a child is seen as powerful because it is not contaminated. And so the various projects, ventures and posterity as long as pure, innocent blood has been shed.

Today many argue that the economy as earlier on alluded to, is responsible for the increased cases of child sacrifice and mutilation. This clearly shows that a trend and ideology of individualism as well as egocentrism has infiltrated the minds of people. It is not ironical that one should kill another person's child, bury the head of that child under his foundation in order to secure wealth and prosperity for himself and his own children. In any case in sacrificial from a neighbour or stranger. What happens today in Uganda is one who is familiar with a child and in most cases knows the family does the abduction/kidnap and there the child is sacrificed. This leaves many families devastated with traumatic effects resulting from the under loss of their children.

Wealth, poverty and economic progress: What African communities had as a value was their communal characteristic of life. Everybody cared for another and with regard to children; the child belonged to the entire community. People worked together to obtain wealth and they shared the yields of their labour together. This brought them joy and fulfillment. This communal life ruled out unproductive competition from the community and the people lived at peace. Several scholars have noted that in the context of collectivism, an individual is obligated to contribute to the community, not only because it is expected of him or her but because the "community is him or her" (Verhoef and Micheal 1997, p.396 cited in Ikwenobe, 2006; Hofstede, 1991, also see Bukuluki, 2013). The concept of a person in the African

\footnotetext{
${ }^{9} \mathrm{Jok}$ is used to refer to a child that is born with special features such as extra fingers or toes and also the manner of birth i.e. if it is a child is born with feet coming out first or 'bottoms' instead of the head. It also includes any other abnormal birth. Such a child will be called Ajok if it is a girl and Ojok if it is a boy.
} 
collectivist world-view is "first and most importantly that of the community...this means not that the individual is selfless, but that the self is the community" (Verhoef and Micheal 1997: 396 cited in Ikwenobe, 2006; also see Bukuluki, 2013). Hofstede (1991: 51) cited in Bukuluki (2013) argues that "collectivism... pertains to societies in which people from birth onwards are integrated into strong, cohesive groups which throughout people's lifetime continue to protect them in exchange for unquestioning loyalty". Ikwenobe noted two important aspects of collectivism--the suppression of the self in the interest of the community or "the idea that the identity of an individual is not separable from the socio-cultural environment" (Ikwenobe 2006: 53; also see Bukuluki, 2013) and the notion of "we are" as a basis for defining identity instead of "I am. In this context, man is viewed as an entity that is not necessary an end to itself but rather a tool to serve the ends of others. However, today, individualism has replaced communalism and the rampant child sacrifice practice may be an outcome of this social change. The zeal for affluence is a sign of a new value system in our societies and hence the enactment of some new practices such as child sacrifice which is a belief system where people think if I sacrifice a child then I will grow rich quickly.

In fact, Walter Burkert in his articles "function and transformation of ritual killing (Burkert in Grimes 1996: 64) noted that "in the experience of killing one perceives the sacredness of life, it is nourished and perpetrated by death. This paradox is embodied, acted out, and generalized in the ritual. Whatever is to endure and be effective must pass through a sacrifice which opens and reseals the abyss of annihilation. Building sacrifice, for example are for this reason widespread. A house, a bridge or a dam will stay strong only if something lies slaughtered beneath it." Note that, this is what most people who sacrifice think and belief. To us, this is not a new belief, the idea is old but choice of the sacrifice i.e. the children is a new one.

Reflecting upon the place of a child in an African traditional context: it was with joy that a child was (is) born, in many communities it is right from conception. As a child grew the whole village took part, and the various rites of passage, do bring people in the community together. The adage" it took a whole village to raise a child in Africa is rooted in this reality. So the practice of kidnapping and killing of children in the name of sacrifice for personal accumulation of wealth had no place in African traditional values. How then can we negotiate between collectivism and radical individualism that has decimated the key values of child rights and child protection? How can we effectively re-socialize some the deviant elements in our society to yes, cherish wealth but remain ethical in their ambitions for wealth accumulation? Using child as a bait for wealth accumulation may be a pointer to lack of creativity and innovation in the process of coping with poverty and in wealth accumulation and sustenance.

It is important for Africans to reconsider their cultural values, with regard to wealth and life in general. Who then has the responsibility of protecting children? They are vulnerable and always unsuspecting. It is important to reflect on this challenge. 


\section{CONCLUDING REMARKS AND A COUPLE OF PRACTICAL PERSPECTIVES}

\section{1. Ethical consequences}

There is a great need to reflect on the ethical implications of child sacrifice. Life is sacred and ought to be respected, but above all preserved. Wealth and affluence can be carried without necessarily terminating one's life. On a more pragmatic note as Ugandans/Africans who and what is influencing our values, choices and minds. Why should we degenerate into careless citizens with no respect for life and others? As scholars, we have the responsibility to objectively point out the fact that every act we do has an ethical dimension which ought to preserve life and not terminate it.

\section{2. Child Protection}

Who has the mandate to protect children? There are obviously structures in society for child protection but how do we go about making them effective? In families and homes, schools, churches, children are getting more vulnerable, who is in charge? Here, the place of choices and values as Africans is challenged by modern trends of work. Parents including mothers as primary care-takers are increasingly becoming bread winners and this has implications for parental availability to take good care and protection of children in families. Alternative institutions and structures have not evolved to provide care for children when parents particularly mothers are at work outside the home environments. There are also very weak formal and informal regulation mechanisms for housekeepers or maids and this has implications for child care and protection.

We conclude that human sacrifice and/or child sacrifice are not part of the traditional African worldview. This is because preservation of life particularly of children is seen as the way to continue the world and life in Africa. In fact in Africa, it is stigmatizing not to have children or at least to be seen to be actively engaged in raising or taking care of children. However, the current social and economic challenges are pushing people to very desperate levels. Some people have been pushed to the wall and end up trying everything that they are told may contribute to helping them get out of their current social and economic predicaments. Unfortunately the social support systems that used to cushion people against the episodic shocks of life are weakening and yet the formal state led social insurance and social assistance schemes are taking too long to develop capacity to help people cope with their social and economic challenges. The few schemes available have suffered from consistent corruption and mismanagement. This has left room for manipulation of people and to adoption of maladaptive strategies for survival including human and child sacrifice. Therefore human and child sacrifice or mutilation may be one of the indicators of state failure to fulfill the state-citizen contract through providing opportunities for people to realize their potentials and the state running away from its responsibility to provide the crucial social protection services. 


\section{References}

[1] Bukuluki P., "When I steal, it is for the benefit of me and you": Is collectivism engendering corruption in Uganda? International Letters of Social and Humanistic Sciences 5 (2013) 27-44.

[2] Bukuluki P., Traditional healing practices among the Baganda in the context of Christianity and Western Medicine, Viennese Journal of Ethno medicine 9(1) (2006) 7- 18.

[3] Bukuluki P., Traditional Healing Practices Among the Baganda in the Context of Christianity and Western Medicine, Viennese Ethnomedicine Newsletter 9(1) (2006) 18-27.

[4] Burkert W., "The Function and Transformation of Ritual Killing”: In Ed., Grimes R. L., Readings in Ritual Studies, Prentice-Hall, Inc. New Jersey, (1996) 62-71.

[5] Davis- Floyd R., Birth as an American Rite of passage: University of California Press, Berkeley: 1992.

[6] Evans-Pritchard E. E., Witchcraft, Oracles, and Magic among the Azande: Clarendon Press, Oxford: 1976.

[7] Foster G. M., "Disease Etiologies in Non-Western Medical Systems", American Anthropologist 78 (1976) 773-782 \& 774-775.

[8] Girard R., "Violence and the Sacred Sacrifice": in R.L., Grimes (ed)., Readings in Ritual Studies, Eaglewood NJ: Prentice Hall, 1996.

[9] Grimes R. L., Readings in Ritual Studies: Prentice-Hall, Inc., New Jersey, 1996.

[10] Hofstede G., Cultures and Organizations: Software of the Mind. London: McGraw-Hill. 1991.

[11] Ikwenobe P., Philosophical Perspectives on Communalism and Morality in African Traditions. New York: Lexington Books, 2006.

[12] Janzen J. M., The Quest for Medical Pluralism in Lower Zaire: University of California Press, London: 1998.

[13] Luc de Heusch, Sacrifice in Africa: A Structural Approach, Bloomington: Indiana University Press, 1985.

[14] Luoga E. J., Witkowski E. T. F., and Balkwill K., Differential utilization and ethnobotany of trees in Kitulanghalo forest reserve and surrounding communal lands, eastern Tanzania, Economic Botany 54(3) (2000) 328-343.

[15] Mbiti J. S., Introduction to African Religion: Praeger, New York, 1975.

[16] Mbiti J. S., African religions and philosophy: London, UK: Biddles, 1989.

[17] Norval A., 'Hybridization', The Im/Purity of the Political: In Sovereignty and Subjectivity, Ed. Edkins, Persram, and Pin-Fat, London: Leine Reiner Publishers (1999) 99-116.

[18] Pouillon J., Malade et médecin: le même et/ou l'autre? Incidences de la psychanalyse Nouvelle Revue de Psychanalyse 1 (1970) 77. 
[19] Tabuti J. R. S., Dhillion S. S., and Lye K. A., Traditional medicine in Bulamogi County, Uganda: Its practitioners, users and viability. Journal of Ethnopharmacology 85 (2003) 119-129.

[20] Ventevogel P., Whiteman's Things: Training and Detraining of Healers in Ghana; Health, Culture and Society, Studies in Medical Anthropology and Sociology; Het Spinhuis, Amsterdam, 1996.

[21] WHO Promotion and Development of Traditional Medicine, Technical Report Series: WHO, Geneva (622) 1978.

[22] Whyte S. R., Questioning Misfortune: The Pragmatics of un-certainty in Eastern Uganda; University of Copenhagen, Cambridge University Press, 1997.

[23] Uganda Police, The State of child sacrifice in the country: A paper Presented at national workshop on child sacrifice at Imperial Royale Hotel, Kampala, $5^{\text {th }}$ November, 2009. 